\title{
Primary renal squamous cell carcinoma: a case report
}

\author{
Primer böbrek skuamöz hücreli karsinomu: Olgu sunumu
}

\author{
Mehmet Faik ÇETiNDAĞ, ${ }^{1}$ Atiye YILMAZ ÖZSAVRAN ${ }^{2}$ \\ 'Department of Radiation Oncology, Ankara Atatürk Training and Research Hospital, Ankara, Turkey \\ ${ }^{2}$ Department of Radiation Oncology, Elazığ Training and Research Hospital, Elazığ, Turkey
}

\begin{abstract}
Pathologic diagnosis of squamous cell carcinoma (SCC) of the kidney is rarely reported in the literature. The disease is aggressive in nature and the prognosis is dismal with a 5-year survival rate of less than \%10. A 74-year-old man admitted with abdominal pain and weight loss. Right nephrectomy was performed. Pathology report delineated moderately differentiated SCC of the kidney. Positron emission tomography demonstrated residual mass and metastatic lymph nodes. Adjuvant treatments with chemotherapy and radiotherapy were applied but the disease was progressed and the patient was dead six months after pathologic diagnosis. Primary SCC is an aggressive tumor and these tumors are strongly associated with renal stones, the patients with renal stones and non-functioning kidney should be carefully examined with newer imaging modalities for early detection of the tumor, and warrants aggressive treatment with surgery followed by adjuvant aggressive combination chemotherapy-radiotherapy that may provide a better outcome.
\end{abstract}

Key words: Chemotherapy; intensity-modulated radiotherapy; radiotherapy; renal squamous cell carcinoma.

\begin{abstract}
Böbreğin skuamöz hücreli karsinom patolojik tanısı literatürde nadiren yer alır. Hastalık agresif tabiatlı, beş yıllık yaşam \%10'dan az ve prognoz kötüdür. Yetmiş dört yaşında erkek hasta karın ağrısı ve kilo kaybı şikayetleri ile başvurdu. Sağ nefrektomi yapıldı. Patoloji raporu orta derece diferansiye skuamöz hücreli böbrek karsinomu varlığını gösterdi. Pozitron emisyon tomografi görüntülerinde kalıntı hastalık ve metastatik lenfadenopatiler izlendi. Adjuvan kemoterapi ve radyoterapi uyguland 1 ancak hastalık ilerledi ve patolojik tanıdan altı ay sonra hasta kaybedildi. Primer skuamöz hücreli karsinom agresif bir tümördür ve böbrek taşı ile güçlü bir ilişkisi vardır. Tümörün erken tespiti için böbrek taşı ve nonfonksiyone böbreği olan hastalar, yeni görüntüleme teknikleri ile incelenmeli ve daha iyi sonuçlar için cerrahi sonrası adjuvan kemoterapi-radyoterapi kombinasyonları ile agresif tedaviler uygulanmalıdır.
\end{abstract}

Anahtar sözcükler: Kemoterapi; yoğunluk ayarlı radyoterapi; radyoterapi; böbrek skuamöz hücreli karsinomu.
Primary renal squamous cell carcinoma (RSCC) is a rare cancer with a variable incidence of about $0.5-15 \%$ of all urothelial cancers and is usually associated with long standing stone disease. Pathologic diagnosis of squamous cell carcinoma of the kidney is rarely reported in literature. There are only isolated case reports and limited case series. ${ }^{[1-5]}$ The disease is aggressive in nature and the prognosis is dismal with a 5-year survival rate of less than $10 \% .^{[3,4]}$ Computed to- mography (CT) is gold standard for diagnosis. ${ }^{[6]}$ RSCC are only identified at late stages, when the patient undergoes surgery for a nonfunctioning kidney. ${ }^{[1,5]}$ Our patient gave a long history of renal calculi which also had an emergency renal stone operation fifty-five years ago. Periodic radiological evaluation should be done in patients undergoing treatment for renal stones. We report here a case of primary RSCC and review the relevant literature. 


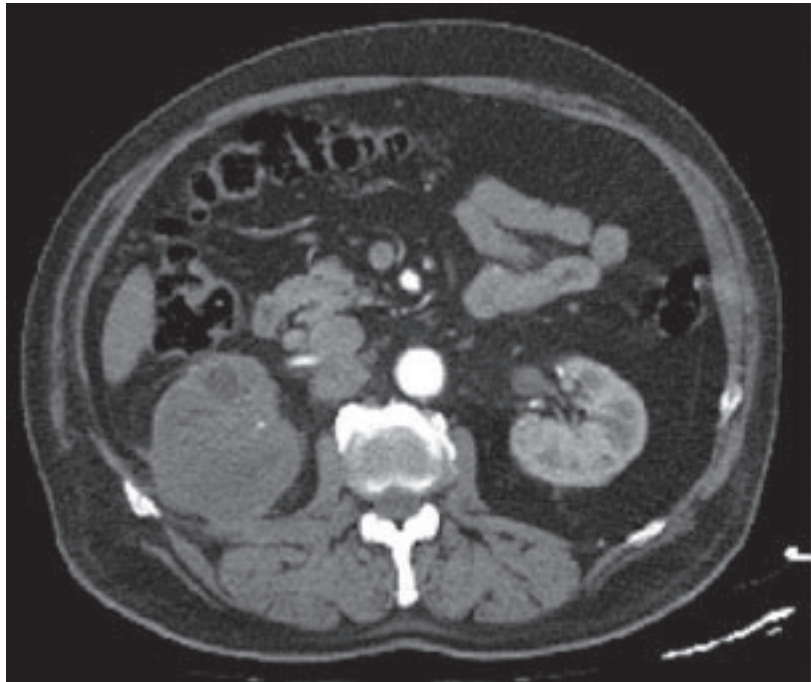

Fig. 1. Contrasted computed tomography of the abdomen at renal level.

\section{CASE REPORT}

A 74-year-old man admitted to our hospital with right side of abdominal pain and weight loss (twenty-five kilograms in six months). Blood chemistries, chest X-ray and examination of the abdomen was unremarkable. Work-up with ultrasound, CT angiography and DRS (5 mCi Tc99mMAG3) were performed. CT and CT angiography delineated a nonfunctioning right kidney which had larger dimensions (without the mass appereance) than left kidney and retrocaval multiple lymph nodes which were measured $15 \times 25 \mathrm{~mm}$

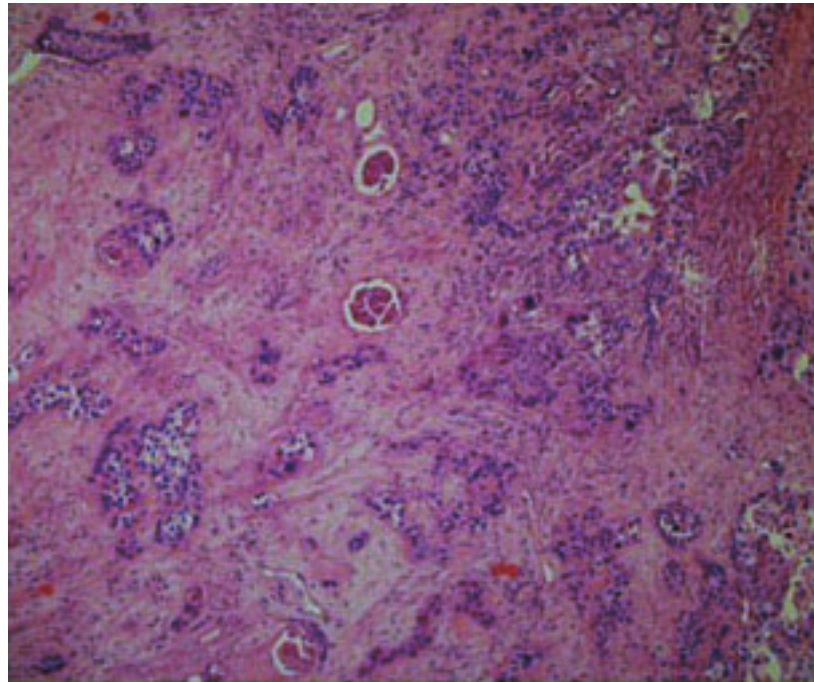

Fig. 2. Cordon like squamous cell carcinoma infiltration between glomerulus (H-E x10).

in maximal diameter (Figure 1). Dynamic renal scintigrafy demonstrated that right kidney and left kidney functions were $10.7 \%$ and $89 \%$ respectively. The patient underwent a right nephrectomy for right-sided nonfunctioning kidney. Pathology specimens showed a moderately differentiated squamous cell carcinoma, infiltrating the perirenal and pelvic fat tissues and one metastatic lymph node (Figure 2). The maximum diameter of tumor was $8 \mathrm{~cm}$ and there were perineural and lymphatic invasion. Additional metastatic work-up with PET showed paraaortic- paracaval malign lymph nodes and right paravertebral malign soft tissue causing

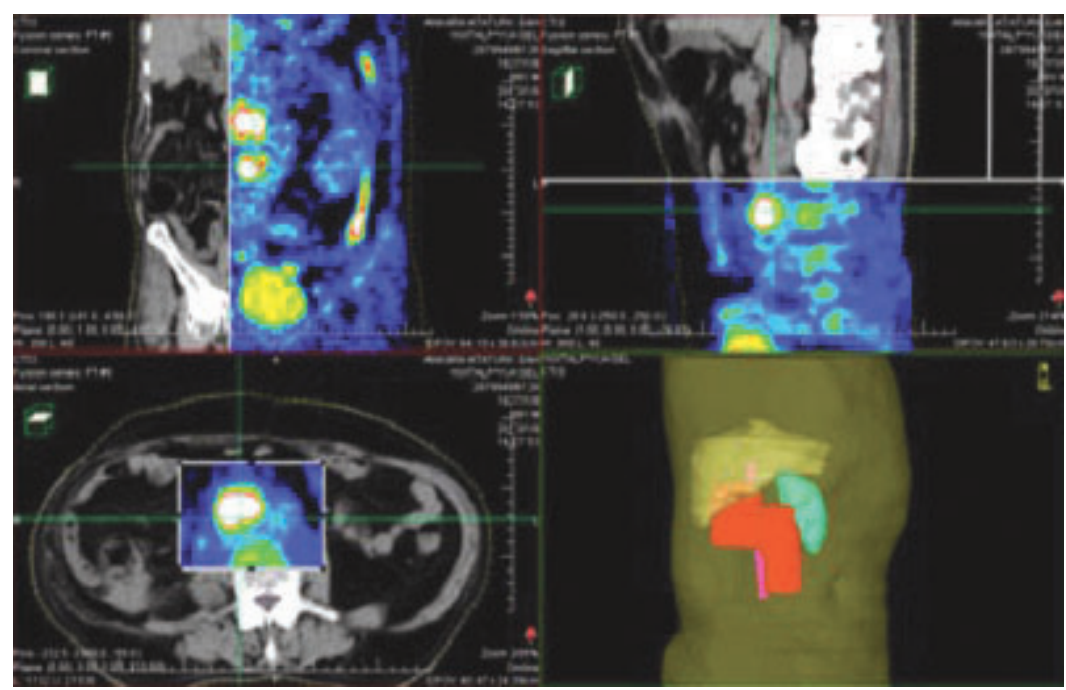

Fig. 3. The imaging of PET and planning tomography fusion and $3 \mathrm{D}$ conturing. 
destruction of the first lumbar vertebra (Figure $3)$. Shortly after the patient was administered first cycle of carboplatin-fluorouracil chemotherapy, he complained that his abdominal pain was getting more severe and was radiating belt style to the whole abdomen. With the second and third cycles of chemotherapy, we applied radiotherapy to the residual mass and involved lymph nodes. Although intensity modulated radiotherapy to a total dose of 56Gy (1.8Gy /day) was planned the patient didn't want to take further radiotherapy after 25 fractions of the therapy (45 Gy). Satisfactory pain palliation was achieved with this dose level of radiotherapy. He also refused to take additional chemotherapy sessions. Six months after pathologic diagnosis he died because of progressive diseases.

\section{DISCUSSION}

Squamous cell carcinoma of the urinary tract is more frequently reported in urinary bladder and male urethra, in it is rarely encountered in renal pelvis. $^{[1-5,7,8]}$

The etiological factors which play in the genesis of this rare malignancy are strongly associated with phenacetin consumption, chronic renal calculi, pyelonephritis and squamous metaplasia. ${ }^{\left[{ }^{8]}\right.} \mathrm{Li}$ MK et al in their study reported incidence of coexisting renal stone in $100 \%$ cases. $^{[9]}$ Urinary calculi was accepted as a main carcinogenic risk factor squamous cell carcinoma. Chronic irritation and infection are believed to induce reactive changes in the urothelium and leads to neoplasia via metaplasia and lecoplakia. Staghorn calculi are most frequently associated with renal pelvis squamous cell carcinoma. ${ }^{[2,5,8]}$ In present case renal squamous cell carcinoma associated with renal calculi, correlated with data given in literature.

Diagnosis of renal SCC is difficult as characteristic features usually not associated with renal SCC, added by imaging techniques which reveals only calculi and hydronephrosis..$^{[7,8]}$ Therefore, initial diagnosis of SCC is mostly based on histological analysis as was seen in present case.

Extensive review of the available medical literature on this rare malignant entity revealed a poor prognosis. ${ }^{[10,11]}$ Nativ et al in their study divided renal SCC in three groups, reported 1 and 2 year survival rates of locally invasive renal SCC 33\% and $22 \%$ respectively. ${ }^{[11]}$

Metastatic disease survey is more shorter with reported median survival of 5 months. ${ }^{[12]}$ In our case, the survival was only 6 months.

Review of literature suggested current primary treatment of renal squamous cell carcinoma is nephrectomy. ${ }^{[7,8,11]}$ Adjuvant chemotherapy or radiotherapy indicated in metastatic disease. ${ }^{[7]}$ Our patient refused to take additional chemotherapy and radiotherapy after 3 sessions chemotherapy and 45 Gy radiotherapy. Six months after pathologic diagnosis he died because of progressive diseases.

In conclusion, primary RSCC is an aggressive tumor, throughout medical literature; these tumors are strongly associated with renal stones, the patients with renal stones and non-functioning kidney should be carefully examined with newer imaging modalities for early detection of the tumor, and warrants aggressive treatment with surgery followed by adjuvant aggressive combination chemotherapy-radiotherapy that may provide a better outcome.

Informed Consent: Written informed consent was obtained from patient who participated in this study.

Conflict of Interest: No conflict of interest was declared by the authors.

Financial Disclosure: The authors declared that this study has received no financial support.

\section{REFERENCES}

1. Jain A, Mittal D, Jindal A, Solanki R, Khatri S, Parikh $\mathrm{A}$, et al. Incidentally detected squamous cell carcinoma of renal pelvis in patients with staghorn calculi: case series with review of the literature. ISRN Oncol 2011;2011:620574

2. Paonessa J, Beck H, Cook S. Squamous cell carcinoma of the renal pelvis associated with kidney stones: a case report. Med Oncol 2011 Dec;28 Suppl 1:392-4.

3. Sivaramakrishna B, Aron M, Ansari MS, Seth A, Goel $\mathrm{R}$, Mundada OP, et al. Squamous cell carcinoma of the renal pelvis manifesting after percutaneous nephrolithotomy for long standing calculus. Int Urol Nephrol 2004;36(2):149-51.

4. Bhaijee F. Squamous cell carcinoma of the renal pelvis. 
Ann Diagn Pathol 2012;16(2):124-7.

5. Van Glabeke E, Chartier-Kastler E, Delcourt A, Cluzel P, Bruel S, Richard F. Epidermoid cancer of the kidney pelvis. [Article in French] Prog Urol 2000;10(6):1200 3. [Abstract]

6. Kabaalioğlu A, Çubuk M. Böbrek Tümörlerinde Radyolojik Değerlendirme. Türkiye Klinikleri Journal of Urology Special Topics 2011;4(1):26-31.

7. Karabulut A, Emir L, Gönültaş M, Nazmi I, Germiyanoğlu C, Demokan E. Squamous cell carcinoma located in the renal caliceal system: A case report and review of the literature. Turkish $\mathrm{J}$ of Cancer 2002;32(1):20-4.

8. Odabas Ö, Karakok M, Yilmaz Y, Atilla MK, Akman E, Aydin S. Squamaous cell carcinoma of kidney. Eastren
J of Medicine 2000;5(1):35-6.

9. Li MK, Cheung WL. Squamous cell carcinoma of the renal pelvis. J Urol 1987;138(2):269-71.

10.Lee TY, Ko SF, Wan YL, Cheng YF, Yang BY, Huang DL, et al. Renal squamous cell carcinoma: CT findings and clinical significance. Abdom Imaging 1998;23(2):203-8.

11. Nativ O, Reiman HM, Lieber MM, Zincke H. Treatment of primary squamous cell carcinoma of the upper urinary tract. Cancer 1991;68(12):2575-8.

12.Singh V, Sinha RJ, Sankhwar SN, Mehrotra B, Ahmed N, Mehrotra S. Squamous Cell Carcinoma of the Kidney - Rarity Redefined: Case Series with Review of Literature. Journal of Cancer Science and Therapy 2010;2(4):82-5. 